\title{
LIG1 Gene
}

National Cancer Institute

\section{Source}

National Cancer Institute. LIG1 Gene. NCI Thesaurus. Code C91269.

This gene plays a role in both replication and base excision repair for DNA. 